aerotactic response via a methyl-accepting chemotaxis protein (3). This poses the question of whether there is a fundamental reason for diversity in the mechanisms of sensing oxygen. One possible explanation lies in the nature of the sensor domain of DcrA. This periplasmically located domain binds a $c$-type haem which may detect molecular oxygen or redox state (2). In $E$. coli it is highly unlikely that aerotaxis could be mediated by a $c$-type cytochrome since this bacterium represses all $c$-type cytochromes under aerobic growth conditions (4).

\section{James Moir}

Centre for Metalloprotein Spectroscopy and Biology, University of East Anglia, Norwich NR4 7TJ, UK.

Tel: +44 1603 592405. Fax: +441603592250.

1. Lindbeck, J. C., Goulbourne, E. A., Johnson, M. S. \& Taylor, B. L. (1995). Aerotaxis in Halobacterium salinarium is methylation-dependent. Microbiology 141, 2945-2953.

2. Fu, R., Wall, J. D. \& Voordouw, G. (1994). DcrA, a $c$-type heme-containing methyl-accepting protein from Desulfovibrio vulgaris Hildenborough, senses the oxygen concentration or redox potential of the environment. $J$ Bacteriol 176, 344-350.

3. Niwano, M. \& Taylor, B. L. (1982). Novel sensory adaptation mechanism in bacterial chemotaxis to oxygen and phospho-transferase substrates. Proc Natl Acad Sci USA 79, 11-15.

4. Iobbinivol, C., Crooke, H., Griffiths, L., Grove, J.,

Hussain, H., Pommier, J., Mejean, V. \& Cole, J. A. (1994). A reassessment of the range of $c$-type cytochromes synthesised by Escherichia coli K-12. FEMS Microbiol Lett $119,89-94$.

\section{Author's reply}

\section{Role of DcrA in aerotaxis}

The dcrA gene product from Desulfovibrio vulgaris is a novel and intriguing protein. Early studies were consistent with a role of DcrA as a methylation-dependent sensor of oxygen concentration or of the environmental redox potential (1). Subsequent investigations have revealed that DcrA is a member of a large sensor protein family in $D$. vulgaris (2), but have not yet established a physiological role for DcrA. Methylation of DcrA is increased in response to dithionite and decreased in response to oxygen, as Moir correctly noted. However, ongoing investigations have failed, so far, to demonstrate a defective aerotaxis phenotype in a $d c r A$ mutant (B. L. Taylor, I. B. Zhulin, S. Patel, R. Fu \& G. Voordouw, unpublished observations).
Therefore, if the DcrA haem moiety binds oxygen, it likely signals to a pathway other than aerotaxis. The possibility that DcrA signals redox information remains a viable and attractive option. Redox taxis has been demonstrated in Azospirillum brasilense (3) and in Escherichia coli (V. A. Bespalov, I. B. Zhulin \& B. L. Taylor, unpublished observations).

\section{Barry L. Taylor}

Department of Microbiology and Molecular Genetics, Loma Linda University, Loma Linda, CA 92350, USA.

Tel: +1 9098244480 . Fax: +1909824 4035 . e-mail: bltaylor@ccmail.llu.edu

1. Fu, R., Wall, J. D. \& Voordouw, G. (1994). DcrA, a $c$-type heme-containing methyl-accepting protein from Desulfovibrio vulgaris Hildenborough, senses the oxygen concentration or redox potential of the environment. $J$ Bacteriol 176, 344-350.

2. Deckers, H. M. \& Voordouw, G. (1994). Identification of a large family for putative chemoreceptor proteins in an ordered library of the Desulfovibrio vulgaris Hildenborough genome. J Bacteriol 176, 351-358.

3. Grishanin, R. N., Chalmina, I. I. \& Zhulin, I. B. (1991). Behaviour of Azospirillum brasilense in a spatial gradient of oxygen and a 'redox' gradient of an artificial electron acceptor. J Gen Microbiol 137, 2781-2785. 